\title{
Land Tax, Justice, and the Unaffordability of Housing: Australian Experience
}

\author{
Viral U. Pandya ${ }^{1} \&$ John Tippett ${ }^{1}$ \\ ${ }^{1}$ Asia Pacific International College, Melbourne, Australia \\ Correspondence: Dr. Viral U. Pandya, Asia Pacific International College, 399 Lonsdale Street, Melbourne 3000, \\ Australia. Tel: 61-9603-5323. E-mail: viralpandya2@ gmail.com
}

Received: August 2, 2017

Accepted: August 23, 2017

Online Published: September 5, 2017

doi:10.5539/ijef.v9n10p86

URL: https://doi.org/10.5539/ijef.v9n10p86

\begin{abstract}
Taxation and tax 'reform' particularly, appears to be a perennial topic, in the major economies of the western world at least. Recently, in Australia there was the "Henry Review" of 2010 - a major review of Australia's tax system including substantial recommendations for tax reform; and observation shows that both sides of politics in Australia spent most of 2016 and part of 2015 talking about tax 'reform'. A key aspect of the Henry Review (2010) is the strong recommendation for a land tax.

Advocacy for land tax has a long and powerful history. Prominent economists lauding the land tax include David Ricardo, Adam Smith, Henry George, Milton Friedman, and Mason Gaffney. The Henry George land tax has been recommended for a very long time, the latest mainstream recommendation for its implementation coming via the above-mentioned Henry Review of Taxation in Australia (2010).

The purpose of this paper is to address the question: is there something special about the natural resource, land, that makes it the subject of so many recommendations for a tax? That is to say, is there anything special about the tax base in the case of a land tax?

This paper argues that the land tax is not just another tax - for the reason that the nature of the base of the tax land - is special. Further, because a land tax would lower the price of land, implementation of a land tax would help solve the housing crisis (the unaffordability of housing). The research findings are different from previous studies because previous studies all focus on the efficiency aspect of taxes, not on any special nature of the tax base.
\end{abstract}

Keywords: land tax, housing affordability, equity, justice

\section{Introduction}

With regard to housing affordability, Australia, especially its five major metropolitan areas, remains "severely unaffordable" in 2015. Among the nine developed nations covered by the 12th Annual Demographia International Housing Affordability Survey, Australia was ranked third-most unaffordable major housing market in 2015.

With regard to the special nature of land, land value taxation (also known as site value taxation) has been known and recommended for a very long time - since the eighteenth century (and probably earlier), particularly for its economic efficiency - and continues to be recommended to this day. Many economists since Smith and Ricardo have advocated a land tax, though it is best known through its advocacy by the nineteenth-century philosopher and economist Henry George (1879). The land tax as originally proposed by George (1879), was proposed not as a tax but rather as the public collection of the periodic economic rental value of land, which rental value - both current and expected - gives land its market price. Market price of land is the capitalised value of expected future rents accruing to the titleholder, and because these rents arise due to the existence of a community and its concomitant economic activity on that land, George argued that these rents belong to that community, the very source of those rents. In the presence of a 'community' of population only one person, land would have no rental value - again indicating that it is the presence of community that is the source of land rents. The value of land (as distinct from the value of improvements to and upon it) owes nothing to the landowner and everything to its surroundings. Thus, the Henry George argument is that land rents belong to the community because they represent community-created value, and should, therefore, be collected publicly. Land tax is currently levied by 
state government(s), but at a rate a long way below 100 per cent: that is to say, land tax as currently applied in Australia is only a partial (weak-form) application of the Henry George land tax proposal.

\subsection{Reason for This Study}

While there is a lengthy literature on land tax and land tax reform, there appears to be no extant study into any special nature of the resource (land), and no study into possible implications of any special nature with regard to the current social economic issue of the unaffordability of housing. This study addresses both these issues. The application to established theory of the land tax of self-evident facts with regard to the nature of the resource, land, makes for a significant improvement of this study over earlier work.

\subsection{Research Questions}

(i) Is there anything special about the natural resource, land, that makes it the basis of so many recommendations for a tax? (ii) Are there implications of any special nature of land with regard to the current social issue of the unaffordability of housing?

Null hypothesis (1): Land is the same as any other economic factor of production; it has no special features or characteristics as a factor of production.

Null hypothesis (2): There are no implications of the nature of the resource, land, with respect to the unaffordability of housing.

\subsection{Methodology}

The method adopted is discussion of the available literature on the question of the tax base in the case of a land tax, coupled with observation of self-evident facts in relation to land. This is with a view to identifying any special features of the resource, land, compared with other economic resources. The research questions, whilst being specific, are not limited to a time period or to any specific area of land, hence the methodology does not involve the use of numeric data. The application of self-evident facts (with regard to the nature of land) to established theory of the land tax is to allow any conclusions to emerge with respect to the efficacy and justice of a land tax.

\subsection{Organisation of the Paper}

The paper addresses the research questions by way of consideration of a brief historical discussion of the rationale for the land tax, and then a critical discussion of specific features of the resource, land, in the light of the available literature. Implications of the special nature of these specific characteristics of land will be suggested and discussed, and discussion outcomes will be related to the research questions in the Conclusion of the paper.

\section{Literature Review}

Specific attention will be paid to whether prior studies have noted any special characteristics of the resource, land; and what has been noted prior will be compared with self-evident facts applicable to this resource.

The Henry George land tax has its basis in justice. This is because of the special nature of the resource, land, and therefore the special nature of land rents. Because land has no cost of production (see following), economic rent of land is unearned income in the hands of the individual titleholder; and this is the reason the land tax is said to have its basis in justice.

David Ricardo's interest in a land value tax was also influenced strongly by considerations of justice. He termed the private appropriation of land rents a serious injustice: "that portion of the produce of the earth which is paid to the landlord for the use of the original and indestructible powers of the soil" (Economist, 2015). Likewise Joseph Stiglitz has expressed concern over the injustice of inequality, which inequality is related to land: "Rich people tend to own a lot of land, poor people very little...land and housing, rather than the distribution of income, is the key to a fairer economy" (The Economist, ibid). Pope Paul VI (1967) said similarly: “...You have been appropriating things that are meant to be for the common use. The earth belongs to everyone, not to the rich".

\section{Specific Characteristics of the Resource, Land}

The special nature of the resource, land - special as distinct from other factors of production - is recognised both historically and currently.

\subsection{Historical Recognition of the Special Nature of Land}

Adam Smith said of the land tax, "nothing could be more reasonable", and Milton Friedman termed it "the least bad tax". 
The special nature of land has long been recognised by all the great philosophic and cultural traditions. In the Bible, the book of Leviticus (chapter 25) speaks of the importance of land to the people, and prescribes a detailed system for its equitable distribution. In the Hindu tradition, in the Mahabharata is recorded: “...Everything springeth from the earth and everything, when destroyed, mergeth into the Earth. The Earth is the stay and refuge of all creatures, and the Earth is eternal. He that hath the Earth, hath the entire universe with its mobile and immobile population" (vol. 2, p. 11).

Adam Smith (1776) emphasised the special nature of land in the Wealth of Nations; and a few years later, in the early part of the nineteenth century, the noted English economist, David Ricardo, spelt out in detail the phenomenon of land rent and its importance in the realm of justice. Around the same period as Adam Smith, a group of French philosophers and economists, the Physiocrats, developed an entire economic system based on the central place and importance of land. Then there is the nineteenth-century, well-known economist and philosopher, Henry George (1879), who presented what he described as the workings of natural law with respect to the special nature of land and its key importance in determining the distribution of wealth. "...To Henry George, man and life were meaningless without land; man was a very part of the earth and to take away from man all that belongs to man would leave him but a disembodied spirit". But it was not metaphysics that George was concerned with in his interest in land. He saw land - in particular, site value - as being central to the cause of large accumulations of wealth existing side-by-side with abject poverty.

\subsection{Current Recognition of the Special Nature of Land}

In Australia, the Henry Taxation Review (2010) presents the case for the implementation of a land tax. Essentially, Henry argues that payment made for the occupancy of land (whether by way of periodic rental payment or by purchase of title) is not a factor payment, and therefore public collection of this payment in the form of a land tax would have no effect on the supply of land. Payment for land neither brings it into existence nor prevents it from going out of existence. This is entirely different for other factors of production; for example, labour. If labour is not paid then its supply will be zero. Recent working papers by both the International Monetary Fund and the Mirlees Review of British Taxation support the land tax (The Economist, op cit). More than 30 countries have some form of land-value taxation, including China, which has both substantial taxes on land values and on the sale price of land (The Economist 2015).

However, in spite of a long history of advocacy, the land tax has not been widely adopted, with the exception of Hong Kong and Singapore (and Denmark to a lesser extent); and Australia in "weak form" via land rates at the local government level.

Notwithstanding the sparse adoption of land tax as policy, there continues to be a strong in-principle argument for it. This argument - based on the nature of the resource, land - has been laid out by the Physiocrats, Adam Smith, Henry George, and, contemporaneously, The Henry Review.

\section{Residential Property Market in Australia}

Australia is a wealthy nation having GDP AUD 1.616 trillion and GDP per capita AUD 66,901 (Quandl, 2014, CIA World Factbook). Internal strength of its economy is one of the major reasons behind the escape of Australia from the 2008 world economic crisis. Australia is one of only nine sovereign states with an AAA rating and stable outlook from the three main rating agencies. All the economic indicators show consistent growth and one of the lowest unemployment rates (6.7\%), weak wage growth rate and low inflation rate (1.5\%) (Macquarie, 2016). In 1985, around $85 \%$ of Australians owned the houses they lived in. Today this figure is less than $50 \%$ (Apt Capital Management Report, 2015).

The residential property market has experienced consistent and high growth since 1999, when the Australian government took the historical decision to abolish the capital gains tax on residential property. The Home Value Index of Australia across the combined capital cities have increased by $7.9 \%$ over the 12 months to April 2015 (CoreLogic RP Data Home Value Index, 2015).

The following table clarifies the effect of the power of a strong economy in continuous growth in prices of residential property in Australia. 
Table 1. Median prices by major cities of Australia

\begin{tabular}{|c|c|c|c|c|c|c|c|c|c|c|c|c|c|c|c|c|}
\hline \multirow{2}{*}{$\begin{array}{c}\text { Quarter } \\
\text { Ended } \\
\text { June }\end{array}$} & \multicolumn{2}{|c|}{ Sydney } & \multicolumn{2}{|c|}{ Melbourne } & \multicolumn{2}{|c|}{ Brisbane } & \multicolumn{2}{|c|}{ Adelaide } & \multicolumn{2}{|c|}{ Perth } & \multicolumn{2}{|c|}{ Canberra } & \multicolumn{2}{|c|}{ Hobart } & \multicolumn{2}{|c|}{ Darwin } \\
\hline & $\$ 1000$ & PerVar & $\$ 1000$ & PerVar & $\$ \mathbf{S}^{\prime} 000$ & PerVar & $\$ ' 000$ & PerVar & $\$ ' 000$ & PerVar & $\$ ' 000$ & PerVar & $\$ ' 000$ & PerVar & $\$ ' 000$ & PerVar \\
\hline \multicolumn{17}{|c|}{ a) Houses: } \\
\hline 2000 & 333.5 & 17.5 & 223.6 & 14.2 & 161.0 & 6.7 & 147.2 & 11.2 & 176.5 & 6.8 & 184.0 & 15.0 & 113.3 & 6.7 & 190.4 & 8.2 \\
\hline 2001 & 364.4 & 9.3 & 240.2 & 7.4 & 165.3 & 2.7 & 156.9 & 6.6 & 184.6 & 4.6 & 210.0 & 14.1 & 112.9 & -0.3 & 187.0 & -1.8 \\
\hline 2002 & 442.5 & 21.4 & 285.1 & 18.7 & 194.9 & 17.9 & 184.6 & 17.6 & 207.0 & 12.1 & 255.1 & 21.5 & 118.3 & 4.8 & 200.0 & 7.0 \\
\hline 2003 & 510.8 & 15.4 & 313.0 & 9.8 & 248.3 & 27.4 & 230.3 & 24.7 & 240.7 & 16.3 & 330.0 & .4 & 148.2 & 25.3 & 206.0 & 3.0 \\
\hline 2004 & 546.0 & 6.9 & 335.0 & 7.0 & 320.5 & 29.1 & 268.0 & 16.4 & 278.2 & 15.6 & 375.0 & 13.7 & 235.5 & 58.8 & 255.0 & 23.8 \\
\hline 2005 & 548.9 & 05 & 348.6 & 4.0 & 327.2 & 2.1 & 286.1 & 6.8 & 316.6 & 13.8 & 368.0 & .9 & 250.1 & 6.2 & 279.8 & 9.7 \\
\hline 2006 & 560.4 & 2.1 & 3 & 7.5 & 350.2 & 7.0 & 308.0 & 7.6 & 470.8 & 48.7 & 390.0 & 6.0 & 284.1 & 13.6 & 350.0 & 25.1 \\
\hline 2007 & 584.8 & 4.3 & 434.9 & 16.1 & 406.1 & 16.0 & 340.7 & 10.6 & 517.0 & 9.8 & 443.3 & 13.7 & 298.5 & 5.1 & 395.0 & 12.9 \\
\hline 2008 & 587.1 & 04 & & 10.7 & 459.3 & 13.1 & & 16.0 & 50 & .8 & & 6.0 & & .7 & & 7.2 \\
\hline 2009 & 586.7 & -0.1 & 47 & -0.4 & 44 & -3.2 & 386.9 & -2.1 & 498.0 & -1.9 & 451.8 & -3.9 & 323.6 & .6 & 469.9 & 11.0 \\
\hline 2010 & 667.1 & 13.7 & 5 & 24.9 & 48 & 9.1 & 429.7 & .1 & 544.3 & 9.3 & 505.0 & 11.8 & 350.3 & 2 & 55 & 18.2 \\
\hline 2011 & 659.4 & -1.2 & 57 & -3.7 & 457.7 & -5.7 & 420.4 & -2.2 & 522.9 & -3.9 & 520.0 & 3.0 & 350.6 & 0.1 & & -7.3 \\
\hline 2012 & 662.5 & 0.5 & 546.6 & -5.3 & 444.9 & -2.8 & 407.9 & -3.0 & 517.1 & -1.1 & 510.0 & -1.9 & 348.1 & -0.7 & 570.0 & 10.7 \\
\hline 2013 & 719.2 & & 567.6 & 3.8 & 463.2 & 4.1 & 411 & 0.9 & 573.1 & 10.8 & 54 & 5.9 & .7 & -1.5 & 61 & 7. \\
\hline 2014 & 845.2 & 17.5 & 623.1 & 11.4 & 492.9 & 6.4 & 438.2 & 6.4 & 597.8 & 4.3 & 55 & 1.9 & 359.2 & 4.8 & 62 & 1.4 \\
\hline 2015 & 1051.4 & 24.4 & 739.0 & 16.9 & 514.5 & 4.4 & 446.9 & 2.0 & 586.2 & -1.9 & 570.0 & 3.6 & 359.3 & 0.0 & 610.0 & -1.7 \\
\hline 2016 & 1047.6 & -0.4 & 774.3 & 4.8 & 52 & 2.2 & 46 & 2 & 553.5 & -5.6 & 60 & 8 & 377.9 & 5.2 & 576.0 & -5.6 \\
\hline \multicolumn{17}{|l|}{ b) Units: } \\
\hline 2000 & 277.3 & & & & 18 & 4 & 10 & .4 & 13 & 9.2 & & 2 & 11 & 12.4 & 14 & -8.0 \\
\hline 2001 & 312.5 & 12.7 & 222.5 & 11.6 & 185.2 & 1.2 & 125.5 & 16.9 & 150.4 & .5 & 155.0 & 9.2 & 102.1 & -11.6 & 141.8 & 1.1 \\
\hline 2002 & & & 264 & 19.0 & 192.7 & 4.0 & 139.8 & & 175.2 & 16.4 & 216.0 & 39.4 & 112.7 & 10.4 & 15 & 7. \\
\hline 2003 & .8 & 7.2 & 280.8 & 6.0 & 212.2 & 10.1 & 181.4 & 9.7 & 210.1 & 19.9 & 260.0 & 20.4 & 142.6 & 26.5 & 157.1 & 2. \\
\hline 2004 & 5.3 & 3. & 284.5 & 1.3 & 256.0 & 20.6 & 203.7 & 12.3 & 222.8 & 6.0 & 300.0 & 15.4 & 206.7 & 45.0 & 190.0 & 20.9 \\
\hline 2005 & 400.5 & 1.3 & 289.2 & 1.6 & 279.3 & 9.1 & 218.9 & 7.5 & 257.5 & 15.6 & 312.0 & 4.0 & 224.6 & 8.7 & 202.5 & 6.6 \\
\hline 2006 & 406.0 & 1.4 & 307.0 & 2 & 324.6 & 16.2 & 229.9 & 5.0 & 345.6 & 34.2 & 325.0 & 4.2 & 245.8 & .4 & 26 & 32.1 \\
\hline 2007 & 411.9 & 1.4 & 348.9 & 13.6 & 367.9 & 13.3 & 263.8 & 14.7 & 384.5 & 11.3 & 355.0 & 9.2 & 245.1 & -0.3 & 279.3 & 4. \\
\hline 2008 & & -0.1 & & 7.7 & 409.3 & 11.3 & & 11.9 & 387.9 & 0.9 & 350.0 & -1.4 & 272.5 & 11.2 & 329.0 & 17. \\
\hline 2009 & 424.0 & 3.0 & 393.0 & 4.6 & 391.3 & -4.4 & 308.7 & 4.6 & 384.5 & -0.9 & 375.0 & 7.1 & 267.1 & -2.0 & 380.1 & 15.5 \\
\hline 2010 & & 15.4 & & 18.4 & 423.3 & 82 & 335.1 & 8.6 & 414.2 & 7.7 & 415.0 & 10.7 & 288.0 & 7.8 & 437.6 & 15.1 \\
\hline 2011 & 500.5 & 2.3 & 468.9 & 0.7 & 406.6 & -3.9 & 333.8 & -0.4 & 401.7 & -3.0 & 420.0 & 1.2 & 288.1 & 0.0 & 425.0 & -2.9 \\
\hline 2012 & 518.8 & 3.7 & 454.4 & -3.1 & 407.1 & 0.1 & 319.0 & -4.4 & 406.7 & 1.2 & 418.0 & -0.5 & 292.0 & 1.3 & 435.0 & 2.4 \\
\hline 20 & & 6 & 465 & 2. & 413.6 & 1.6 & 328 & 3.0 & 433.5 & 6.6 & 412.3 & -1.4 & 304.6 & 4.3 & 464.0 & 6.7 \\
\hline 2014 & 615.4 & 11.7 & 491.5 & 5.6 & 434.9 & 5.2 & 340.8 & 3.7 & 445.7 & $2.8 /$ & 415.0 & 0.7 & 295.6 & -3.0 & 485.0 & 4.5 \\
\hline 2015 & 708.3 & 15.1 & 512.4 & 4.3 & 445.0 & 2.3 & 334.5 & -1.8 & 431.0 & -3.3 & 421.0 & 1.4 & 296.4 & 0.3 & 480.0 & -1.0 \\
\hline 2016 & 729.8 & 3.0 & 527.3 & 2.9 & 424.7 & -4.6 & 342.2 & 2.3 & 403.1 & -6.5 & 410.3 & -2.6 & 301.5 & 1.7 & 500.2 & 4.2 \\
\hline
\end{tabular}

Note. APM PriceFinder, Real Estate Institute of Australia - 2017.

For the period 2000-2016, the median price of residential property increased from $\$ 180,300$ to $\$ 564,800$. The following Figure illustrates the continuous rise in residential property prices.

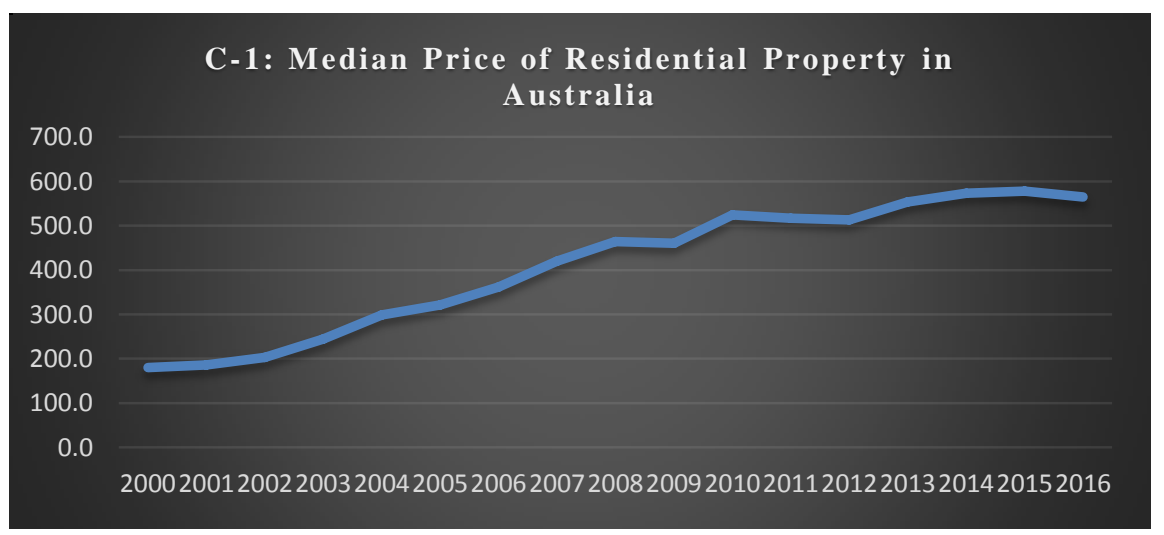

Figure 1. Median price of residential property in Australia 
The median price is derived from the actual median price of all the capital cities of Australia for this period. The actual price of all the capital cities is taken as sample for deriving median price of residential property for the country. Today, housing price is dramatically rising in certain parts of Australia (Melbourne \& Sydney), but it's an issue for whole country as most of the population is living in the surrounding suburbs of these two cities.

\section{Land Tax Revenue in Australia}

The property tax is one of most efficient and considerable source of income for states in Australia because of which there are many socio-economic considerations affecting the decision. Since, it has direct relation with real estate industry, the tax revenue is extremely increased.

Table 2. Tax revenue from immovable property

\begin{tabular}{ccc}
\hline \multicolumn{3}{c}{ Tax Revenue from immovable property } \\
\hline Year & Total Tax $(\mathbf{m})$ & Percentage Variance \\
\hline $2005-06$ & 13,276 & - \\
$2006-07$ & 14,801 & 11.49 \\
$2007-08$ & 15,597 & 5.38 \\
$2008-09$ & 17,645 & 13.13 \\
$2009-10$ & 18,660 & 5.75 \\
$2010-11$ & 19,880 & 6.54 \\
$2011-12$ & 20,730 & 4.28 \\
$2012-13$ & 21,778 & 5.06 \\
$2013-14$ & 23,586 & 8.30 \\
$2014-15$ & 25,021 & 6.08 \\
\hline
\end{tabular}

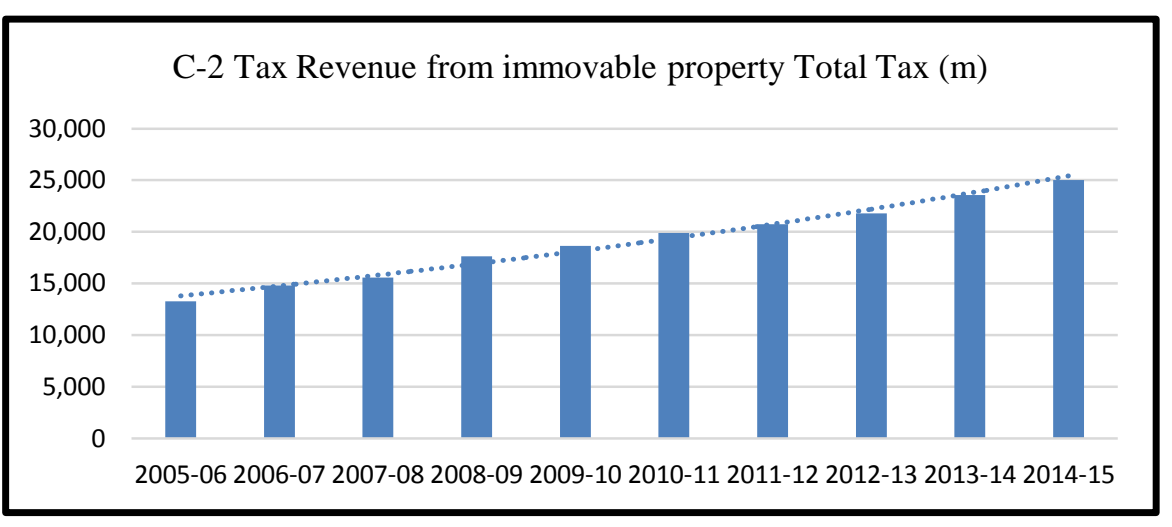

Figure 2. Tax revenue from immovable property (Total tax)

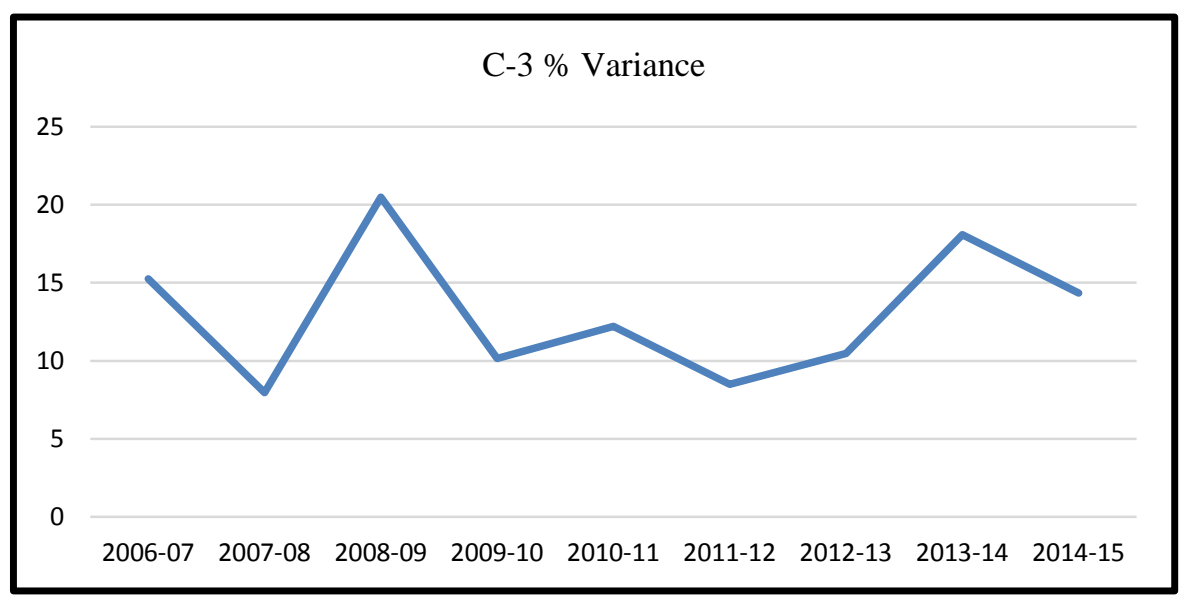

Figure 3. Percentage variance 
The table and charts above clearly explains the phenomenal increase in overall property tax income for government. It has annual double digit growth since year 2010. The government requires capital to meet its socio - economic and welfare expenditure. The land tax and property tax are now most crucial and delighted source of revenue for any government as they have been considered as source of income. But side effect of this, it may create unnecessary inflation in real estate pricing and that will motivate investors to invest in real estate in comparison with other investment avenues. This will be resulted into continuous demand of the property market.

\section{Results/Analysis}

\subsection{Share of Loans to Residential Purchasers by Purchaser Type}

As previously stated, today less than 50\% Australians owned the houses they lived in and demand in housing property is increasing with limited increase in population. Due the government approach and overall equation of property market in Australia, the outcome can be measured in two ways:

\subsubsection{Share of Loans to Residential Purchasers by Purchaser Type}

Table 3. Residential property purchaser

\begin{tabular}{lccc}
\hline \multicolumn{4}{c}{ Residential Property Purchaser } \\
\hline & $\mathbf{1 5}$ years to 2015/16 & $\mathbf{2 0 1 4 / 1 5}$ & $\mathbf{2 0 1 5 / 1 6}$ \\
First Home Buyers & $15 \%$ & $12 \%$ & $13 \%$ \\
Non - first home buyers & $43 \%$ & $37 \%$ & $43 \%$ \\
Investors & $42 \%$ & $51 \%$ & $44 \%$ \\
\hline
\end{tabular}

Source: Australian Burau of Statistics, April 2017.

Overseas investors and non - first home buyers are always key driving force for residential property market in Australia. Therefore, the political and government strategies and policies for real estate sector will have higher influence of them. Only 13\% of buyers purchase for their first home. So, only $13 \%$ of target customers will be seeking stable or less rates of the residential property market.

\subsubsection{Total Foreign Investment in Residential Property Market}

Residential property market is one of the major sources of foreign investment in Australia. The government is expected to formulate policy that suits these foreign investors. Therefore, government controls the release of land as it's required to have control on inflation. In current time of global competition, this is also referred one of the major social indicator of the country and its growth. The following table gives picture of recent foreign investments in residential property market.

Table 4. Foreign investment ( $\$$ billion)

\begin{tabular}{lc}
\hline Year & Foreign Investment (\$ billion) \\
\hline 2010 & 61 \\
2011 & 18.9 \\
2012 & 17.5 \\
2013 & 15.8 \\
2014 & 33.8 \\
2015 & 60.8 \\
\hline
\end{tabular}

\subsection{Specific Reasons for Land Being of a Special Nature}

There are four distinct reasons land is different from the other factors of production; four distinct reasons it is special.

\subsubsection{The Need for It Is Universal and Indispensable}

With respect to some minimum quantity (area) of land required for human existence, the demand for land is perfectly inelastic with respect to price. Human existence is impossible in the absence of access to land. The demand for it is universal and undeniable. Even those who are poverty-stricken and can afford to pay nothing for access to land (because they have nothing to pay with) are either given access (in the form of accommodation run by a charitable service) or they take access (by way of sleeping on park benches or the like). 
Irrespective of the particular human activity in question, that activity can only be carried out in the presence of access to land. Access to a site of land is a necessary condition for any, and all, human activity, including, of course, that of simply living. It is necessary for purposes of conducting a business that there be access to land; it is necessary for flying an aeroplane or sailing a ship that there be access to land; it is necessary for establishing a home that there be access to land. The amount of land needed for the conduct of the multifarious human activities varies widely from activity to activity, but nonetheless, the universal need for it is undeniable.

\subsubsection{Land is Not a Product}

Land is not produced. It is not a product. Hence, the supply of land is perfectly inelastic with respect to price. Its existence is not the outcome of human effort. The production of goods and services involves the input of human effort. Land is not produced because it does not have to be produced. It exists. It is given. And it is given to the whole human race, to everybody. This is so because, as already noted, everybody (every body) needs it. And, as appears to be the case universally, what is needed - 'needed' in the sense that human life is impossible without it - is provided. It is part of the natural set-up of the created order.

Now because land does not have to be produced it has no cost of production. Improvements made to and upon it do have a cost of production, but the land itself does not. Hence, any payment made for land is not made to cover its cost of production. This is a very different situation from that which prevails in the case of man-made goods and services. Payment for them is made to cover their costs of production, and hence to prevent resources needed for their production from transferring to an alternative use. If no payment were made for man-made goods and services, production of them would cease. In contrast, land does not become land only when a purchaser parts with his dollars in payment thereof. Land does not and cannot cease to exist; and it exists, in its entirety, irrespective of payments made for it or not. The supply of land does not respond to its price.

\subsubsection{Land Has a Market Price only Because of Demand Influences}

The market price of land arises solely from the demand for it; or, to put this differently, land attracts a market price solely via the forces of demand for it, not via its cost of production. Again, this is in contrast with human-made goods and services, which have a market price that arises in the first instance from their costs of production. A site of land has a market price because it is given this price - given it by intending occupants. That price is entirely unrelated to any cost of production of that land (which, as already noted, is zero). It is related to the level of services provided to and around that land (such as roads and public utilities); and to increasing demand for that land. The price of land - including an increasing price over time - is given to land by those who want it.

This fact (that land has a market price only by virtue of being given one) was obvious to new arrivals in previously-uninhabited countries. The first settlers simply found the land and then put it to use. They were not hindered from using it because its price was too high! It had no price, and it had no price because there was no community to give it one. It is only when a community is established (i.e. multiple "demanders" of land) that a price for land arises. The establishment of a community results in people wanting and needing access to land. Price is given to land by the population of people living on and around it.

These three reasons, namely: (i) everybody needs it and cannot live without it, (ii) it has zero cost of production, and (iii) its price arises only as a consequence of demand for it and irrespective of cost factors, make land an entirely different factor from the other factors of production and entirely different from human-made goods and services.

Thus, land (and hence a land tax) is not some quaint idea applicable to pre-industrial-revolution history. It is not a resource that was important only in the agrarian age. It is, of course, the basis of agriculture, but it is the same resource that house are built on in the twenty-first century, it is the same resource that is at the basis of our bustling cities of teeming millions of people, it is the same resource that houses are built on, and it is the very resource on which locational value rests.

\subsubsection{The Issue of Security}

There is one further reason that land is special than indicated by these three reasons, and that is to do with security. Because everybody needs land - nothing can happen without access to it, not even life itself ownership of it leads to a sense of security. Contrarily, non-ownership of land engenders insecurity in those who are dispossessed. Naturally, a sense of insecurity fosters action toward alleviating that sense; in particular, action directed toward becoming a landowner.

The desire to own land appears to be innate in the human being. It is a strong desire, as may be seen from the so-called "great Australian dream" of people to own their own home; and, on a larger scale indeed, from the 
thoughts of the founding fathers of the United States who, following John Locke, believed that security of one's property was intimately related to one's freedom (Johnson, 1997, p. 212). But perhaps the greatest example in recorded history of this desire is the desire for property ownership and security by the descendants of those who "knew what it felt like to be homeless for forty years as they wandered through the desert" (Sacks, 2011).

Respected historian and described by some as "one of the greatest friends of sanity", Hilaire Belloc, described the strength and ramifications of the instinct to own property:

"It has been found in practice, and the truth is witnessed to by the instincts in all of us, that widely distributed property as a condition of freedom is necessary to the normal satisfaction of human nature. In its absence general culture ultimately fails and so certainly does citizenship. The cells of the body politic are atrophied and the mass of men have not even, at last, an opinion of their own, but are moulded by the few who retain ownership of land and endowments and reserves. So property is essential to a full life..." (Belloc, 2002 (1936), pp. 27-28).

In Belloc's view, property is necessary to the satisfaction of human nature, not optional.

These, then, are the four reasons land is special. The first three reasons are matters of fact. The fourth, whilst not exactly a matter of "fact", appears to be the way humankind all around the world think and behave with regard to the possession (or lack thereof) of land.

\section{Implications of the Special Nature of Land}

It is being suggested that there are important implications of land having special characteristics, and that if these special characteristics are not recognised and land is treated just as any other factor of production is treated, there will be serious negative implications: in particular, that there will be a loss of justice in economic affairs. Specifically:

With respect to the price of land: in most markets, price serves two functions. First, it serves as the allocating mechanism - and price does serve this function in the case of land. Second, it acts as a signal to producers to supply more, or less, of the product; i.e. to alter the quantity supplied. Price does not, cannot serve this function in the case of land.

Because land is not a product and therefore involves no factors of production, payment for it in the event of a purchase is a transfer payment between two individuals, not a factor payment (a payment to factors employed in the production process; Layton et al. p. 256). Consequently, price assistance schemes, such as Australia's "first-home buyers' scheme" to less-well-off individuals, which have the appearance of being of help to such individuals, are not of assistance at all in the end analysis. The end result of such schemes is simply to increase the price of land. The immediate effect of these schemes is assistance to the buyer, but this assistance is lost very quickly. Because the 'assistance' increases the buyer's ability to pay, it is transferred to the previous title-holder of the land concerned, in the form of a higher price being paid for that land. In other words, the ability to pay more - as a result of the assistance scheme - is reflected in a higher price for land. And therefore home buyers 'assistance' schemes have the opposite effect of that intended.

\section{Conclusion}

Payment for site value of land is payment for advantage: the advantage bestowed on a site by the presence and activity of community. It does not arise from individual effort. This advantage includes the presence of infrastructure surrounding the site which makes it attractive for its intended purpose; for example, social amenities and attractive streets which make a site attractive to retail shoppers. Therefore, a land tax is the capture of the value of this infrastructure - which has been paid for by public money - and therefore it is the application of justice.

This conclusion supports previous studies. For example, The Economist (op cit.) puts the question this way: "We have a choice: either recapture the rent for the public good (whether to offset other taxes and/or a citizens' dividend), or allow wealthy developers and banks to privatise the rent and force everyone else to subsidise that with taxes on their production and cuts in government services". The peculiar characteristics of land particularly the universal demand for it and the fact that it is not a product - make it a special factor of production; and yet it is usually attributed no more economic importance than the buildings built upon it or the creatures that move about on it.

In addition to this study supporting the evidence of previous studies, particularly with respect to the question of justice, it provides new insight on the question housing affordability. A land tax reduces the market price of land and, given the significance of the cost of land in the total cost of a house, a land tax would therefore assist in addressing the pressing social problem of housing being unaffordable, particularly to new entrants to the market. 


\section{References}

Anderson, P. J. (2008). The Secret Life of Real Estate: How it moves and why. Shepheard-Walwyn, London.

APM PriceFinder, Real Estate Institute of Australia - 2017.

Apt Capital Management Report 2015. Australia's Housing Bubble, Is the luck running out?

Australian Bureau of Statistics, 15 April 2017.

Belloc, H. (2002) [1936]. An Essay on the Restoration of Property. Norfolk: HIS Press.

Bible. King James translation, Cambridge University Press.

CoreLogic RP Data Home Value Index report - 2015.

Economist (The). (2015). Land-value tax: Why Henry George had a point.

George, H. (1879) [1979]. Progress and Poverty: An inquiry into the cause of industrial depressions and of increase of want with increase of wealth. Robert Schalkenbach Foundation, New York.

Harrison, F. (1983). The Power in the Land. Shepheard-Walwyn, London.

Henry, K. (2010). The Henry Taxation Review.

International Housing Affordability Survey, 2015.

Johnson, P. (1997). A History of the American People. Harper, New York.

Layton, A. et al. (2012). Economics for Today. Cengage Learning Australia.

Macquarie Global report on real estate -2016.

Mahabharata (The), Munshiram Manoharlal Publishers, Delhi (1997 edition).

Pope Paul, VI. (1967). Populorum Progressio 23. Retrieved from http://www.wikipedia.org/wiki/Land_value

Productivity commission. (2004). First Home Ownership, Report No. 28, Melbourne.

Quandl, CIA World Factbook - 2014.

Smith, A. (1776). The Wealth of Nations.

Tippett, J. (2012). A Philosopher's Take on Economics. Delphian Books.

\section{Copyrights}

Copyright for this article is retained by the author(s), with first publication rights granted to the journal.

This is an open-access article distributed under the terms and conditions of the Creative Commons Attribution license (http://creativecommons.org/licenses/by/4.0/). 